\title{
ANALISIS PENYEBAB TERJADINYA ANEMIA PADA IBU HAMIL
}

\author{
Sariestya Rismawati, \& Etin Rohmatin \\ Dosen Jurusan Kebidanan Poltekkes Kemenkes Tasikmalaya
}

\begin{abstract}
Abstrak
Penelitian ini bertujuan untuk mengetahui faktor-faktor penyebab terjadinya anemia pada ibu hamil di wilayah kerja Puskesmas Rajapolah Kabupaten Tasikmalaya Tahun 2017. Penelitian termasuk penelitian kuantitatif dengan rancangan case control, dengan jumlah kelompok kasus dan keloompok kontrol masing-masing 25 orang. Analisis univariat menggunakan distribusi frekuensi, analisis bivariat menggunakan chi kuadrat dan multivariat menggunakan regresi logistik berganda. Hasil penelitian menunjukkan tidak ada hubungan yang signifikan antara umur ibu $(0,185)$, paritas $(0,107)$, pekerjaan ibu $(0,552)$, status gizi ibu $(0,123)$, pendidikan ibu $(0,390)$ dan pengetahuan $(0,258)$ terhadapkejadian anemia. Konsumsi Fe $(0,001)$ dan kunjungan ANC $(0,004)$ berhubungan dengan kejadian anemia pada ibu hamil $(0,009)$. Berdasarkan hasil penelitian tersebut dapat disimpulkan bahwa konsumsi Fe yang paling berpengaruh terhadap kejadian anemia pada ibu hamil, sehingga disarankan bidan atau tenaga kesehatan memantau dan memotivasi ibu hamil untuk melakukan pemeriksaan kehamilan dan meminum tablet Fe secara teratur.
\end{abstract}

Kata kunci : anemia, konsumsi Fe, kunjungan ANC

\begin{abstract}
This study aimed to derminate the factors causing anemia in pregnant women in Rajapolah public health centre year 2017. This research was are quantitative research with case control design, with the sample case and control group each 25 people. Univariate analysis used frequency distribution, bivariate analysis used chi square and multivariate with multiple logistic regression. the result showed no significant relationship between maternal age (0.185), parity (0.107), maternal occupation (0.552), maternal nutritional status (0.123), maternal education (0.390) and knowledge (0.258) on the incidence of anemia. Fe (0.001) and ANC (0.004) intakes were associated with anemia in pregnant women. Fe consumption is the factor most related to the incidence of anemia in pregnant women (0.009). based on the result of this study can be concluded that the most influental factor to anemia in pregnancy women $\mathrm{Fe}$ consumption, so it is advisable midwife orhealth workers monitor and motivate pregnant women to perform pregnancy examination and taking tablet Fe regularly.
\end{abstract}

Keywords : anemia, Fe consumption, ANC visit

\section{PENDAHULUAN}

AKI di Indonesia masih cukup tinggi.

Survei Demografi Kesehatan Indonesia (SDKI) tahun 2014 menyebutkan bahwa AKI di Indonesia 214 per 100.000 kelahiran hidup (Depkes RI, 2013). Sekitar 748 kasus kematian ibu terjadi di Jawa Barat dari total 5.019 kasus di Indonesia. (Profil Dinkes Jabar, 2013). Tingginya AKI secara global terkait dengan penyebab langsung dan penyebab tidak langsung. Penyebab langsung kematian ibu yaitu perdarahan, eklampsia, partus lama, komplikasi aborsi, dan infeksi, sedangkan salah satu faktor penyebab tidak langsung kematian ibu hamil adalah anemia. Risiko dari penyebab langsung ini akan semakin meningkat bila ibu menderita anemia (Manuaba, 2007).

Anemia pada ibu hamil adalah keadaan dimana seorang ibu hamil mengalami defisiensi zat besi dalam darahnya. Anemia atau sering disebut kurang darah adalah keadaan di mana darah merah kurang dari normal, dan 
biasanya yang digunakan sebagai dasar adalah kadar Hemoglobin ( $\mathrm{Hb})$. WHO menetapkan kejadian anemia hamil berkisar antara $20 \%$ sampai $89 \%$ dengan menentukan $\mathrm{Hb} 11$ gr\% sebagai dasarnya (Depkes RI, 2009).

Anemia dalam kehamilan merupakan masalah kesehatan yang utama di negara berkembang dengan tingkat morbiditas tinggi pada ibu hamil. Kejadian anemia di dunia menduduki urutan ke tiga dengan prevalensi anemia pada ibu hamil $74 \%$. Kebanyakan anemia dalam kehamilan disebabkan oleh defisiensi besi dan pendarahan akut, bahkan jarak keduanya saling berinteraksi (Adawiyani, 2013). Pravalensi anemia ibu hamil di Indonesia adalah $70 \%$ atau 7 dari 10 wanita hamil menderita anemia. Tingginya pravalensi ini merupakan masalah yang tengah dihadapi pemerintah Indonesia saat ini (Admin, 2012).

Anemia gizi besi merupakan masalah gizi utama bagi semua kelompok umur dengan prevalensi paling tinggi pada ibu hamil (70\%) (Supariasa, 2002). Pada kehamilan relatif terjadi anemia karena ibu hamil mengalami hemodilusi dengan peningkatan volume $30 \%$ sampai $40 \%$ yang puncaknya pada kehamilan 32 sampai 34 minggu (Manuaba, 1998). Menurut Ikatan Bidan Indonesia (IBI, 2006) untuk mendeteksi anemia pada kehamilan maka pemeriksaan kadar $\mathrm{Hb}$ ibu hamil harus dilakukan pada kunjungan pertama dan minggu ke 28. Bila kadar $\mathrm{Hb}$ kurang dari 11 gram\% maka dinyatakan ibu menderita anemia.

Anemia pada ibu hamil dapat bersifat multifaktor, dari yang murni defisiensi besi, folat, B12 dan karena penyakit malaria/hemolitik atau sickle cell. Anemia dalam kehamilan dipengaruhi oleh kemiskinan, dimana asupan gizi sangat kurang, ketimpangan gender, serta ketidaktahuan tentang pola makan yang benar. Ibu hamil memerlukan banyak zat gizi untuk memenuhi kebutuhan tubuh pada diri dan janinnya. Bagi ibu hamil, anemia berperan pada peningkatan prevalensi kematian dan kesakitan ibu (Tarwoto, 2009 dan Proverawati, 2011).

Anemia dalam kehamilan yang paling sering dijumpai adalah anemia gizi besi, hal ini disebabkan kurangnya asupan gizi dalam makanan karena gangguan reabsorbsi, gangguan penggunaan atau pendarahan (Breymann, 2005). Menurut Depkes RI (2002) dalam Niver (2002), kejadian anemia pada kehamilan dapat terjadi karena beberapa hal diantaranya gizi ibu hamil, kepatuhan meminum tablet $\mathrm{Fe}$, pemeriksaan kehamilan, paritas ibu, dan hal lain yang juga ditunjang oleh rendahnya tingkat pendidikan serta kurangnya pengetahuan ibu tentang bahaya anemia pada kehamilan. Kasus anemia dalam kehamilan ini sebenarnya dapat dicegah melalui kegiatan yang efektif seperti pemeriksaan kehamilan berkesinambungan pada tenaga kesehatan, pemberian gizi yang memadai, peningkatan pengetahuan ibu tentang bahaya anemia dalam kehamilan, pemberian dan konsumsi tablet Fe yang teratur dan lain-lain.

\section{METODE PENELITIAN}

Penelitian ini termasuk penelitian kuantitatif dengan rancangan case control dan pendekatan retrospektif (Nursalam, 2003). Populasi penelitian yaitu seluruh ibu hamil di wilayah kerja Puskesmas Rajapolah dan sampel diambil berdasarkan penghitungan didapatkan 50 orang dengan 25 orang kelompok kasus dan 25 orang kelompok kontrol. Responden yang dapat mengikuti penelitian ini yaitu yang memenuhi kriteria inklusi diantaranya tidak memiliki penyekit penyerta pada kehamilan dan terdata sebagai sasaran di wilayah kerja Puskesmas Rajapolah. Analisis univariat menggunakan distribusi frekuensi, analisis bivariat menggunakan chi kuadrat dan multivariat menggunakan regresi logistik berganda. 


\section{HASIL PENELITIAN}

Tabel 1. Pengaruh Karakteristik Responden Terhadap Kejadian Anemia pada Ibu Hamil di Wilayah Kerja Puskesmas Rajapolah Kabupaten Tasikmalaya

\begin{tabular}{|c|c|c|c|c|c|c|c|}
\hline \multirow{3}{*}{ No } & \multirow{3}{*}{ Karakteristik } & \multicolumn{4}{|c|}{ Kejadian Anemia } & \multirow{3}{*}{ OR } & \multirow{3}{*}{$\begin{array}{c}P \\
\text { value }\end{array}$} \\
\hline & & \multicolumn{2}{|c|}{ Kasus } & \multicolumn{2}{|c|}{ Kontrol } & & \\
\hline & & $f$ & $\%$ & $f$ & $\%$ & & \\
\hline \multirow[t]{3}{*}{1} & Umur & & & & & & \\
\hline & $<20$ th dan $>35$ th & 8 & 66,7 & 4 & 33,3 & \multirow{2}{*}{$\begin{array}{c}2,471 \\
(0,634-9,625)\end{array}$} & \multirow{2}{*}{0,185} \\
\hline & 20-35 tahun & 17 & 44,7 & 21 & 55,3 & & \\
\hline \multirow[t]{3}{*}{2} & Tingkat Pendidikan & & & & & & \\
\hline & Rendah & 16 & 55,2 & 13 & 44,8 & \multirow{2}{*}{$\begin{array}{c}1,641 \\
(0,529-5,093)\end{array}$} & \multirow{2}{*}{0,390} \\
\hline & Tinggi & 9 & 42,9 & 12 & 57,1 & & \\
\hline \multirow[t]{3}{*}{3} & Pekerjaan & & & & & & \\
\hline & Tidak bekerja & 24 & 51,1 & 23 & 48,9 & \multirow{2}{*}{$\begin{array}{c}2,087 \\
(0,177-24,615)\end{array}$} & \multirow{2}{*}{0,552} \\
\hline & Bekerja & 1 & 33,3 & 2 & 66,7 & & \\
\hline \multirow[t]{3}{*}{4} & Paritas & & & & & & \\
\hline & 1 kali & 9 & 69,2 & 4 & 30,8 & \multirow{2}{*}{$(0,769-11,340)$} & \multirow{2}{*}{0,107} \\
\hline & $>1$ kali & 16 & 43,2 & 21 & 56,8 & & \\
\hline \multirow[t]{3}{*}{5} & Status Gizi & & & & & & \\
\hline & Gizi Kurang & 20 & 57,1 & 15 & 42,9 & \multirow{2}{*}{$\begin{array}{c}2,667 \\
(0,753-9,450)\end{array}$} & \multirow{2}{*}{0,123} \\
\hline & Gizi Baik & 5 & 33,3 & 10 & 66,7 & & \\
\hline
\end{tabular}

Tabel 1 menunjukkan bahwa umur ibu hamil $\quad(p=0,185, \quad O R=2,471), \quad$ tingkat pendidikan $(p=0,390, O R=1,641)$, pekerjaan $(p=0,552, \quad O R=2,087)$, paritas $(p=0,107$, $\mathrm{OR}=2,953)$ dan status gizi $(p=0,123$, $\mathrm{OR}=2,667)$ memiliki nilai $\mathrm{p}$ lebih besar dari $\mathrm{p}$ value sehingga tidak memiliki pengaruh yang berarti. Nilai OR umur menunjukkan bahwa ibu hamil dengan umur $<20$ tahun dan $>35$ tahun beresiko mengalami anemia dibandingkan dengan umur ibu 20-35 tahun, nilai OR tingkat pendidikan menunjukkan ibu hamil dengan tingkat pendidikan rendah beresiko mengalami anemia dibandingkan dengan ibu hamil dengan tingkat pendidikan tinggi, nilai OR pekerjaan memperlihatkan bahwa ibu hamil yang bekerja beresiko mengalami anemia dibandingkan dengan ibu hamil yang tidak bekerja, nilai OR paritas memperlihatkan bahwa bahwa ibu hamil dengan paritas $>1$ kali beresiko mengalami anemia dibandingkan dengan ibu yang baru pertama kali hamil dan nilai OR status gizi menunjukkan bahwa ibu hamil dengan gizi kurang beresiko mengalami anemia dibandingkan dengan ibu hamil dengan gizi baik.

Tabel 2. Pengaruh Konsumsi Fe Terhadap Kejadian Anemia pada Ibu Hamil

\begin{tabular}{|c|c|c|c|c|}
\hline \multirow{2}{*}{$\begin{array}{c}\text { Konsumsi } \\
\text { Fe }\end{array}$} & \multicolumn{3}{|c|}{ Kejadian Anemia } \\
\cline { 2 - 5 } & \multicolumn{2}{|c|}{ Kasus } & \multicolumn{2}{c|}{ Kontrol } \\
\cline { 2 - 5 } & $\mathbf{f}$ & $\%$ & $\mathbf{f}$ & $\%$ \\
\hline$<90$ tablet & 15 & 78,9 & 4 & 21,1 \\
\hline$>90$ tablet & 10 & 32,3 & 21 & 67,7 \\
\hline Jumlah & 25 & 50,0 & 25 & 50,0 \\
\hline$=0,001$ dan OR $=7,875(2,071-29,940)$
\end{tabular}

Tabel 2 menunjukkan bahwa nilai $p$ value sebesar 0,001 lebih kecil daripada nilai $\alpha(0,05)$, maka $\mathrm{H} 0$ ditolak yang artinya ada pengaruh konsumsi $\mathrm{Fe}$ terhadap kejadian anemia. Nilai Odd Ratio (OR) 7,875 yang artinya ibu hamil dengan konsumsi $\mathrm{Fe}$ $<90$ tablet beresiko mengalami anemia dibandingkan dengan ibu hamil yang mengkonsumsi tablet $\geq 90$ tablet. 
Tabel 3. Pengaruh Pemeriksaan ANC

Terhadap Kejadian Anemia

\begin{tabular}{|c|c|c|c|c|}
\hline \multirow{2}{*}{$\begin{array}{c}\text { Pemeriksaan } \\
\text { ANC }\end{array}$} & \multicolumn{3}{|c|}{ Kejadian Anemia } \\
\cline { 2 - 5 } & $\mathbf{2}$ & $\%$ & $\mathbf{f}$ & $\%$ \\
\cline { 2 - 5 } & $\mathbf{f}$ & 100 & 0 & 0 \\
\hline Tidak teratur & 7 & 41,9 & 25 & 58,1 \\
\hline Teratur & 18 & 25 & \multicolumn{3}{c|}{ Kontrol } \\
\hline Jumlah & 25 & 50,0 & 25 & 50,0 \\
\hline$=0,004$ dan OR $=3,389(1,680-3,398)$
\end{tabular}

Tabel 3 menunjukkan nilai $\mathrm{p}$ value sebesar 0,004 lebih kecil daripada nilai $\alpha$ $(0,05)$, maka $\mathrm{HO}$ ditolak yang artinya ada pengaruh pemeriksaan ANC terhadap kejadian anemia. Nilai Odd Ratio (OR) diperoleh 3,389 yang artinya ibu hamil yang tidak melakukan pemeriksaan ANC secara teratur beresiko mengalami anemia dibandingkan dengan ibu hamil yang teratur melakukan pemeriksaan ANC.

Tabel 4. Pengaruh Pengetahuan Terhadap Kejadian Anemia

\begin{tabular}{|c|c|c|c|c|}
\hline \multirow{2}{*}{ Pengetahuan } & \multicolumn{3}{|c|}{ Kontrol } \\
\cline { 2 - 5 } & \multicolumn{2}{|c|}{ Kasus } & \multicolumn{2}{c|}{ Ko } \\
\cline { 2 - 5 } & $\mathbf{f}$ & $\%$ & $\mathbf{f}$ & $\%$ \\
\hline Kurang & 10 & 41,7 & 10 & 41,7 \\
\hline Baik & 15 & 57,7 & 15 & 57,7 \\
\hline Jumlah & 25 & 50,0 & 25 & 50,0 \\
\hline
\end{tabular}

Tabel 4 menunjukkan bahwa nilai $p$ value sebesar 0,258 lebih besar daripada nilai $\alpha(0,05)$, maka $\mathrm{H} 0$ ditolak yang artinya tidak ada pengaruh pengetahuan terhadap kejadian anemia. Nilai Odd Ratio (OR) diperoleh 0,524 yang artinya bahwa ibu hamil yang memiliki pengetahuan kurang beresiko mengalami anemia dibandingkan dengan ibu hamil dengan pengetahuan baik.

Tabel 5. Analisis Regresi Logistik Berganda

\begin{tabular}{|c|c|c|c|}
\hline Step & $\begin{array}{c}-\mathbf{2} \text { Log } \\
\text { Likelihood }\end{array}$ & $\begin{array}{c}\text { Cox \& } \\
\text { Snell R } \\
\text { Square }\end{array}$ & $\begin{array}{c}\text { Nagelkerke } \\
\text { R Square }\end{array}$ \\
\hline 1 & $34.466^{\mathrm{a}}$ & .502 & .669 \\
\hline
\end{tabular}

a. Estimation terminated at iteration number 20
R Square pada tabel 5 menunjukkan nilai sebesar 0,669 atau $66,9 \%$. Hal ini berarti, variabilitas variabel dependen dapat dijelaskan oleh variabilitas variabel independen sebesar $66,9 \%$. Artinya, seluruh variabel independen mempengaruhi variabel dependen secara serentak pada kisaran $66,9 \%$, sedangkan $33,1 \%$ lainnya dipengaruhi atau dijelaskan oleh variabelvariabel yang tidak dimasukkan dalam penelitian ini. Variabel yang mempunyai pengaruh terhadap kejadian anemia adalah variabel status gizi $(0,010)$ dan konsumsi tablet Fe $(0,009)$, sedangkan variabel yang berpengaruh terhadap kejadian anemia adalah konsumsi $\mathrm{Fe}$.

\section{PEMBAHASAN}

1. Pengaruh Umur Terhadap Kejadian Anemia

Semakin muda dan tua umur ibu hamil, akan berpengaruh terhadap kebutuhan gizi. Dalam penelitian ini menunjukkan bahwa umur tidak berpengaruh terhadap kejadian anemia, hal ini sejalan dengan penelitian Lulu (2009), pada pasien di Puskesmas Kecamatan Pasar Minggu Jakarta Selatan, yang menyatakan bahwa tidak ada perbedaan antara ibu yang berumur 20 tahun dan $>35$ tahun dengan umur ibu antara 20-35 tahun. Penelitian Ariyani (2016) juga menunjukkan tidak adanya hubungan antara umur ibu dengan kejadian anemia pada kehamilan. Menurut Syaifudin (2012) dalam penelitiannya menyatakan bahwa terdapat kecendrungan semakin tua umur ibu hamil maka presentasi anemia semakin besar. Pada penelitian ini belum menunjukkan adanya kecenderungan makin tua umur ibu hamil maka kejadian anemia makin besar. Hal ini dikarenakan proporsi sampelnya tidak seimbang dimana proporsi paling besar $(80 \%)$ ialah dari usia ibu saat hamil yaitu 20-35 tahun baik di kelompok kasus maupun kontrol. 
2. Pengaruh Tingkat Pendidikan Terhadap Kejadian Anemia

Hasil penelitian menunjukkan tingkat pendidikan tidak berpengaruh dan sejalan dengan penelitian yang dilakukan oleh Lestari (2008). Lebih lanjut dijelaskan bahwa tidak terdapat perbedaan bermakna antara kelompok anemia dan tidak anemia, namun ibu dari latar pendidikan rendah beresiko mengalami anemia dibandingkan dengan ibu dari latar belakang pendidikan tinggi. Makin tinggi tingkat pendidikan ibu hamil, maka makin tinggi kesadaran pentingnya kesehatan. Ibu yang menyelesaikan pendidikan dasar enam tahun akan menurunkan angka kematian bayi secara signifikan dibandingkan dengan ibu yang tidak tamat sekolah dasar (Yahya dan Ngalimun, 2004).

\section{Pengaruh Pekerjaan Terhadap Kejadian Anemia}

Variabel ini tidak berpengaruh dan sejalan dengan penelitian yang dilakukan oleh Ngurah Rai (2016) yang menyatakan bahwa pekerjaan tidak berhubungan dengan kejadian anemia. Responden yang tidak bekerja cenderung memiliki status sosial ekonomi yang lebih rendah dan sebagian besar pendapatannya bergantung pada penghasilan suami untuk memenuhi kebutuhannya. Dari hasil analisis univariat, responden sebagian besar ibu rumah tangga. Status pekerjaan erat kaitannya dengan sosial ekonomi. Ibu hamil dengan status pekerjaan tidak bekerja hanya sebagai ibu rumah tangga merupakan faktor resiko terjadinya anemia.

\section{Pengaruh Paritas Terhadap Kejadian Anemia}

Berdasarkan hasil uji statistik menunjukkan bahwa paritas tidak berpengaruh terhadap kejadian anemia pada ibu hamil. Hal ini disebabkan karena baik ibu dengan paritas 1 ataupun lebih beresiko mengalami anemia. Hasil penelitian ini bertolak belakang dengan teori yang menyatakan bahwa seorang ibu yang sering melahirkan mempunyai risiko mengalami anemia pada kehamilan berikutnya apabila tidak memperhatikan kebutuhan nutrisi, karena selama hamil zat gizi akan berbagi untuk ibu dan janin. Semakin sering wanita melahirkan maka semakin besar risiko kehilangan darah dan berdampak pada penurunan kadar $\mathrm{Hb}$. Setiap kali wanita melahirkan, jumlah zat besi yang hilang diperkirakan sebesar $250 \mathrm{mg}$ (Wikjosastro, 2007). Hal yang sama ditemukan oleh Rohas (2010) yaitu bahwa ibu hamil dengan paritas tinggi berisiko 33,0 kali untuk anemia.

\section{Pengaruh Status Gizi Terhadap Kejadian Anemia}

Berdasarkan hasil uji statistik bivariat menunjukkan bahwa tidak terdapat pengaruh status gizi terhadap kejadian anemia pada ibu hamil. Namun, setelah dilakukan uji regresi logistik terlihat bahwa status gizi berpengaruh terhadap anemia pada ibu hamil. Peningkatan berat badan di trimester pertama relatif sedikit, tidak naik atau berkurang karena muntah-muntah. Peningkatan berat badan yang cukup pesat terjadi di trimester 2 dan 3, sehingga perlu pemantauan ekstra terhadap berat badan. Pemenuhan nutrisi yang baik sangat dibutuhkan pada masa kehamilan untuk memenuhi kebutuhan tumbuh kembang janin, pemeliharaan kesehatan ibu dan persediaan laktasi. Salah satu kekurangan nutrisi pada ibu hamil dapat mengakibatkan anemia.

\section{Pengaruh Konsumsi $\mathrm{Fe}$ Terhadap Kejadian Anemia \\ Berdasarkan hasil uji statistik} menunjukkan bahwa terdapat pengaruh konsumsi $\mathrm{Fe}$ terhadap kejadian anemia pada ibu hamil. Ibu hamil dianjurkan mengkonsumsi tablet $\mathrm{Fe}$ minimal 90 tablet selama kehamilan, karena pada wanita hamil cenderung mengalami defisiensi baik zat besi maupun folat. Kebutuhan ibu hamil akan $\mathrm{Fe}$ meningkat untuk pembentukan plasenta dan sel darah merah sebesar 200$300 \%$. Zat besi yang diperlukan selama hamil ialah $1040 \mathrm{mg}$. Dari jumlah ini, $200 \mathrm{mg}$ 
Fe tertahan oleh tubuh ketika melahirkan dan $840 \mathrm{mg}$ sisanya hilang. Sebanyak 300 $\mathrm{mg}$ besi ditransfer ke janin, dengan rincian 50-75 mg untuk pembentukan plasenta, 450 mg untuk menambah jumlah sel darah merah, dan $200 \mathrm{mg}$ lenyap ketika melahirkan. Ibu hamil yang kurang minum tablet besi atau dalam seminggu hanya mengkonsumsi satu tablet memiliki resiko mengalami anemia dua belas kali lipat dibanding dengan ibu hamil yang mengkonsumsi tablet rutin setiap hari (Khatijah, 2010). Rendahnya tingkatan kepatuhan ibu hamil mengkonsumsi tablet Fe dipengaruhi oleh beberapa faktor seperti pengetahuan, cara benar minum obat, efek samping tablet $\mathrm{Fe}$ dan perilaku petugas kesehatan dalam mensosialisakan tentang pentingnya tablet $\mathrm{Fe}$ serta dukungan suami.

\section{Pengaruh Kunjungan ANC Terhadap Kejadian Anemia}

Berdasarkan hasil uji statistik bivariat menunjukkan bahwa terdapat pengaruh kunjungan ANC terhadap kejadian anemia pada ibu hamil. Semakin teratur ibu dalam ANC, maka akan terhindar dari resiko anemia. Kunjungan ANC merupakan upaya menjaga agar kehamilan sehat melalui pemeriksaan fisik, pemberian suplemen serta penyuluhan kesehatan ibu hamil. Kunjungan ANC yang teratur agar segera terdeteksinya berbagai faktor risiko kehamilan salah satunya anemia. Dengan ANC keadaan anemia ibu akan lebih dini terdeteksi, sebab pada tahap awal anemia pada ibu hamil jarang sekali menimbulkan keluhan bermakna.

\section{Pengaruh Pengetahuan Terhadap Kejadian Anemia \\ Berdasarkan hasil uji statistik} menunjukkan bahwa tidak terdapat pengaruh pengetahuan terhadap kejadian anemia pada ibu hamil. Hal ini disebabkan karena baik ibu hamil yang mempunyai pengetahuan tinggi maupun rendah beresiko mengalami kejadian anemia. Pengetahuan seseorang tentang anemia akan mempengaruhi terhadap perilaku dirinya terhadap anemia, bila pengetahuan ibu tentang anemia kurang, tidak merasa butuh, atau tidak tahu manfaatnya maka mereka tidak mau minum $\mathrm{Fe}$ untuk menjaga kehamilannya. Apabila pengetahuan ibu tentang anemia baik, diharapkan ibu akan melakukan usaha untuk mencegah agar dirinya tidak terkena anemia. Namun disamping itu, ibu dapat memiliki perilaku yang baik misalnya melakukan kunjungan ANC teratur dan mengonsumsi Fe setiap hari sesuai dengan arahan dari tenaga kesehatan sehingga tidak mengalami anemia.

\section{KESIMPULAN}

Sebagian besar responden baik pada kelompok kasus maupun kontrol berada pada rentang umur tidak resiko yaitu 20-35 tahun, dengan tingkat pendidikan rendah, tidak bekerja, paritas $>1$, status gizi kurang, konsumsi $\mathrm{Fe}$ yang kurang. Pengetahuan responden pada kelompok kasus lebih baik daripada kelompok kontrol. Tidak ada hubungan signifikan antara umur, paritas, pendidikan, pekerjaan, pengetahuan terhadap kejadian anemia pada ibu hamil. Kunjungan ANC dan konsumsi $\mathrm{Fe}$ berpengaruh terhadap kejadian anemia pada ibu hamil. Konsumsi $\mathrm{Fe}$ adalah variabel paling berpengaruh terhadap kejadian anemia pada ibu hamil

Tenaga kesehatan diharapkan melakukan pemantauan konsumsi $\mathrm{Fe}$ dan status gizi bagi ibu hamil. Suami dan keluarga ikut berperan dalam melakukan pemantauan dan motivasi dalam konsumsi Fe bagi ibu hamil. Pemantapan buku KIA dan lembar observasi konsumsi $\mathrm{Fe}$ yang telah diberikan oleh Kemenkes

\section{DAFTAR PUSTAKA}

Adawiyani. 2013. Pengaruh Pemberian Booklet Anemia Terhadap Pengetahuan, Kepatuhan Minum Tablet Tambah Darah dan Kadar Hemoglobin Ibu Hamil di Unit Rawat Jalan Rumkital Dr. Ramelan Surabaya. Surabaya: Jurnal IImiah Google Cendekia. Tersedia di 
http://mediainfo.sourceforge.net diakses tanggal 24 Agustus 2016.

Admin. 2012. Cara Mengkonsumsi Tablet

Penambah Darah Yang Benar.

Tersedia dalam

http://www.tipsbunda.com diakses

tanggal 24 Agustus 2016.

Ariyani. 2016. Arisman. 2005. Penilaian

Status Gizi Perorangan dalam Gizi dalam Daur Kehidupan. Jakarta: EGC.

Breymann, Christian. 2005. Anemia in

Pregnancy and the Puerperium. 1st ed.

Bremen : International Medical

Publisher

Departemen Kesehatan RI. 2013. Riset Kesehatan Dasar. Jakarta: Badan Penelitian dan Pengembangan Kesehatan Kementrian Kesehatan RI.

Depkes RI, 2009. Profil Kesehatan Indonesia Tahun 2008. Jakarta: Depkes RI.

Dinas Kesehatan Jawa Barat. 2013. Profil Kesehatan Jawa Barat Tahun 2013.

IBI. 2006. Faktor Kejadian Anemia Pada Ibu Hamil. Jakarta

Khatijah. 2010. Prevalen Anemia Semasa Mengandung dan Faktor-Faktor dan Mempengaruhinya di Johor Baru Malaysian. Jurnal of Public Health Medicine, 1 (10).

Lestari, S. Hubungan Antara Usia Ibu Hamil, Paritas, Pendidikan, dan Pengetahuan Ibu Hamil tentang Anemia dengan Kejadian Anemia pada Ibu Hamil di
Rumah Bersalin Utami Kecamatan Batangan Kabupaten Pati Terdapat dalam : http://digilib.unimus.ac.id. Diakses tanggal 31 Oktober 2017. Lulu. 2009. Faktor Yang Berhubungan Dengan Status Anemia Pada Asuhan Antenatal di Puskesmas Kecamatan Pasar Minggu Jakarta Selatan. Tesis.: FKM UI. Depok

Manuaba, I.B.G. 2007. Kapita Selekta Penatalaksanaan Rutin Obstetric Ginekologi dan KB. Jakarta : EGC.

Ngurah Rai. 2016. Analisis Faktor-Faktor Yang Berhubungan Dengan Kadar Hemoglobin Pada Ibu Hamil. Jurnal eBiomedik (eBm), Volume 4, Nomor 2.

Proverawati, A. 2011. Anemia dan Anemia Kehamilan. Yogyakarta: Nuha Medika.

Puskesmas Rajapolah. 2015. Laporan Puskesmas Rajapolah.

Rohas. 2010. Faktor-faktor Yang Berhubungan Dengan Anemia Pada Ibu Hamil di Puskesmas Melur Kecamatan Sukajadi Pekanbaru Tahun 2010.

Supariasa. 2002. Penilaian Status Gizi. Jakarta : Penerbit Kedokteran EGC.

Wiknjosastro. 2007. Buku Acuan Pelayanan Kesehatan Maternal dan Neonatal. Jakarta : Yayasan Bina Pustaka

Yahya dan Ngalimun. 2004. Pedoman Penyelenggaraan Pelayanan Obstetri Maternal Neonatal. PT Raja Grafindo. Persada. Jakarta. 